\title{
Poverty Alleviation in Nigeria: An Assessment of Government Policies
}

\author{
AdamuBuba (Lead Researcher) \\ Department of General Studies, Federal Polytechnic, Bauchi. Inuwa Abdu Ibrahim (Co-Researcher) \\ Department of Public Administration, Federal Polytechnic, Bauchi \\ (This is a Tetfund Sponsored Institutional Based Research (IBR) 2016)
}

\begin{abstract}
Executive Summary:-Every human being needs a range of basic necessities, such as food, water, clothing, shelter, education, and health care, for his or her daily life. The economic condition of lacking these essential goods and services to meet basic needs of life has become the major reasons while nations embark on policies and program that would engender development and ultimately reduce poverty to its barest minimum. While poverty is universal, it is severe in developing countries. Efforts were made by previous governments in Nigeria through initiation of policies and programmes that will at least reduce poverty level to the barest minimum. This study assessed government policies on poverty alleviation aimed at alleviating poverty in Nigeria. The instrument used in the research is the survey type of questionnaire administration. The study area was Bauchi Local Government. The research added to the existing theoretical significances on poverty alleviation and the outcome will guide policy makers in the future while formulating policies on poverty alleviation; it alsoadvances the efficiency of entrepreneurial centers and their roles in alleviating poverty. While addressing the shortcomings and inadequacies of previous and current government policies towards poverty alleviation, the study highlighted and the stake holders advised accordingly.
\end{abstract}

Keywords:Poverty, Alleviation, Assessment, Government Policies, Bauchi State

\section{INTRODUCTION}

The rising profile of poverty in Nigeria is expecting a troubling measurement as experimental studies have proved. Nigeria, asub-Saharan African nation, has in recent times half of its populace living in miserable poverty (Ojo, 2008). Likewise, thepublication of the Federal Office of Statistics (1996) uncovers that poverty has been gigantic, pervasive, and overwhelms a largeproportion of the Nigerian culture. Abiola and Olaopa (2008) state that the scourge of destitution in Nigeria is anincontrovertible reality, which results in craving, lack of awareness, hunger, sickness, unemployment, poor access to creditfacilities, and bleak future and additionally a general level of human sadness. After decades of social policies based on the inclusion of the poor, poverty is again being treated as a problem of marginalization. As Procacci (2007:5) puts it, "marginalization puts poverty further apart from the whole of society. As far as poverty is concerned, the fundamental right to a minimum of resources for not starving is not enough for organizing a social response to its increase. Social exclusion confirms a dual society and appears more as a symptom of a social fracture than as a solution against it. Thus, under the Millennium Development Goals, today's development strategies try to put under question the reverse link between growth and inequality by tackling poverty under multiple dimensions. This inevitably demands that not only extreme poverty is targeted, nor individual trajectories, but rather that multiple processes producing poverty within society are also tackled.

Sen (1992) in his hypothesis onpoverty infers poverty as not a characteristic marvel inside a bigger edge of disparity issues; rather it can be wiped out if individuals are empowered to wind up self-sufficient from requirements. No genuine improvement is conceivable if fundamental needs are unmet and bigger and bigger strata of the populace are kept in a state of reliance. Dismissing the possibility of poverty as a characteristic article, and its certainty in human social orders situates our scrutinizing towards solid social works on treating destitution, their changes and their belongings. As Manning (2007:2) observe, "rapid and sustained poverty reduction requires 'pro-poor growth', that is a pace and pattern of growth that enhances the ability of poor women and men to participate in, contribute to and benefit from growth. In essence, growth should be broad based across sectors and regions and inclusive of the large part of the workforce that poor men and women make up. Also, policies for sustaining growth such as those aiming at strengthening institutional capacity, promoting democratic and effective governance should increase poor people's incentives, opportunities and capabilities for employment so they can participate in and benefit from growth" This simply means fast and managed povertyreduction requires 'master poor development', that is a pace and example of development that improves the capacity of poor ladies and men to take an interest in, add to and profit by development. Generally, development ought to be wide based crosswise over segments and areas and comprehensive of the huge part of the workforce that poor men and ladies make up. Additionally, strategies for maintaining development, for 
example, those going for reinforcing institutional limit, advancing equitable and compelling administration ought to increase poor people's inducements, openings and proficiencies for engagement so they can contribute to and also benefit from growth.

\section{PROBLEM STATEMENT/JUSTIFICATION}

It has been known in Nigeria that each government leaves on one type of poverty reduction methodology or the other. Be that as it may, what has stayed unanswered is the degree to which these projects have affected on the poor - the objective populace. Late studies on the subject poverty and its reduction agencies and additionally programs demonstrate that impressive gap exists between the target objectivereducing or eliminating poverty - and accomplishment. It appears that the endeavors of different governments are inadequate and accordingly very little has been done to actualize the advantages. For poverty reduction agencies, their outcomes don't appear to legitimize the gigantic monetary portions to them. Poor individuals' view of formal poverty reduction establishments are to a great extent very ineffective and insignificance in their lives as government poverty reduction exercises contribute little in their battles to survive and once in a while help them to escape the problem. The most disturbing problem is the fact that the huge amount of money voted for these policies only succeeded in deepening poverty thereby multiplying the number of persons falling into that category instead of moving out of it.Based on the foregoing, this research will find outthe problems hindering poverty alleviation in Nigeria and how has the lack of efficient and effective entrepreneurial alternatives hampering the alleviation of poverty in Nigeria. It will also look at the how the failure of government policies affected poverty alleviation in Nigeria. It will conclude by establishing a link between the growing unemployment situations in Nigeria to poverty

\section{Objective(s) of the Study}

i. To determine the impact of poverty reduction policies in Bauchi State

ii. To assess the performance of government policies on poverty alleviation in Bauchi state

iii. To determine the efficiency of entrepreneurial development centres in Bauchi local government area

iv. To determine the state of unemployment in Bauchi local government area

\section{LITERATURE REVIEW}

There is no generally acknowledged meaning of poverty. At same time, there is dependably the trouble in choosing where to adhere to a meaningful boundary between "poor people" and the "non poor". As indicated by World Bank Report (2002), poverty is the powerlessness to accomplish a base way of life. The report developed some files in light of a base level of utilization so as to demonstrate the commonsense part of neediness. These incorporate absence of access to assets, absence of instruction and aptitudes, weakness, ailing health, absence of political opportunity and voice, poor access to water and sanitation, helplessness to stuns, savagery and wrongdoing, political separation and underestimation. So also, the United Nations Human Development (UNHD) has presented the utilization of such different records, for example, child mortality rate, grade school enrolment proportion and number of persons per doctor to quantify poverty in a nation (UNDP HDI:2002).

Aluko (1995) alludes to neediness as an absence of summon over fundamental utilization needs. There is a deficient level of utilization, for example, ascend to inadequate sustenance, apparel and safe house. He takes note of that the ordinary idea portrays neediness as a condition in which individuals are underneath a particular least wage level and can't give or fulfill the fundamental necessities of life required for an adequate way of life. The clarification, notwithstanding, neglected to give the realistic photo of the individuals who are poor, how to change their conditions and what to do. As indicated by Shaffer (2001:9) the idea of destitution has experienced four changes over the previous decade. To start with, there has been a movement from a physiological model of hardship to a social model of hardship. The social model is about consolidating issues of political and financial rights and social equity into the counter neediness automatic system. Second, there has been reestablished accentuation put on the idea of defenselessness and its relationship to destitution. Third, the idea of imbalance and its relationship to destitution has opened a focal anxiety. Fourth, the possibility that neediness ought to be conceptualized as the infringement of fundamental human rights has been carefully contended by UN framework organizations.

Nwaobi (2003) affirms that Nigeria exhibits a No-win situation on poverty reduction. The nation is rich, yet the general population is poor. As noted by Omotola (2008), Nigeria is lavishly supplied and the nation's riches possibilities show in the types of common, geological, andsocioeconomic variables. With this condition, Nigeria ought to rank among the wealthiest nations of the world that shouldhave no business with amazing neediness. Nonetheless, Okpe and Abu (2009) perspicaciously comment that Nigeria haswitnessed a stupendous increment in the level of poverty. As per them, the destitution level remained at 74.2 percent inthe year 2000 . 
Taking a glimpse at the records from the Federal Office of Statistics, Garba (2006) uncovers that around 15 percent of the populationwas poor in 1960; the figure rose to 28 percent in 1980 and, by 1996, the frequency of destitution in Nigeria was 66 percentor 76.6 million individuals. Garba (2006) similarly comments that the UN Human Poverty Index, in 1999, set Nigeria among the 25 poorest countries on the planet. As indicated by the UNDP (2010), the populace in neediness is given as 68.7 million, asof 2004. This is extremely grievous when one considers the way that Nigeria has had over $\$ 300$ billion in oil and gasrevenues since political freedom (Awa, 1983). Awa further thunders that up to 95 percent of these extraordinary riches are controlled byabout .01 percent of the populace.

Destitution mitigation is a standout amongst the most troublesome difficulties confronting any nation in the creating scene where, on the normal, lion's share of the populace is viewed as poor. Confirmations in Nigeria demonstrate that the quantity of those in destitution has kept on expanding. For instance the quantity of those in neediness expanded from $27 \%$ in 1980 to $46 \%$ in 1985 and to 67\% in 1996, by 1999 it expanded to more than $70 \%$ (Ogwumike, 2001). Destitution reduction programs in Nigeria are means through which the administration intends to patch up and recreate the economy. The high frequency of destitution in the nation has made neediness easing techniques critical strategy choices throughout the years with fluctuating results. Povertylessening techniques going from Operation Feed the Nation of 1978, the Green Revolution of 1982, the Directorate of Foods Roads and Rural Infrastructures DFFRI, the National Directorate for Employment NDE, poverty alleviation program, PAP up to the National Poverty Eradication Program, NAPEP were all endeavors made by different governments in the nation to control the danger the menace posed to the society

\section{ASSESSMENT OF GOVERNMENT POLICIES ON POVERTY REDUCTION STRATEGIES IN NIGERIA}

This part is for assessing the execution of poverty mitigation measures attempted exclusive within the period 1999 - Date. The following area contains the writing survey and hypothetical issues. It also evaluates the penury decrease methods in Nigeria from 1999 to date and the last segment contains conclusion and rounding up.Data was accumulated through reports, distributions, the web and other optional fountains of information. Particularly information were gathered from the Central Bank of Nigeria and the National Poverty Eradication Council (NAPEC). The gathered information was examined utilizing basic substance examination. The decision of this method of examination was refined by the gathered information and the goal of the study.

\section{REVIEW OF LITERATURE AND THEORETICAL CONCEPTS}

There is no standard meaning of poverty in view of its multi-dimensional nature. Poverty or destitution is normally characterized as a circumstance of low wage or low consumption. It can likewise be seen as a circumstance in which people can't meet the fundamental necessities of life, for example, nourishment, attire, cover, training, security and wellbeing. Ajakaiye and Adeyeye (2000) conceptualize poverty as an element of instruction, wellbeing, kid mortality and other demographic variables. Poverty to them is the accessibility or generally of the above parameters. Basically poverty can be seen as a circumstance in which an individual can't due to monetary, social, political and mental debilitation, give himself and his family the barest essential necessities of life.

\section{BASES AND CONCERNS OF POVERTY}

Obadan (1997) recognized some elements as the reasons for poverty among which seem to be; insufficient access to occupation opportunities, deficient physical resources, lacking access to business sectors, obliteration of regular assets, absence of energy to take an interest in configuration of improvement projects and lacking access to help for those living at the edge. On the results of destitution, Akuetal (1997) opined that there is general loss of trust in a general public stricken by poverty and this renders government approaches inadequate. Destitution additionally brings about expanding the delicacy and helplessness of individuals from society to outer impacts. Moreover, poverty makes creation remain to a great extent subsistence because of absence of capital required for extension. Work gets to be escalated and minimal profitability stays low. It is important to briefly look at some methods of poverty alleviation techniques for further clarification on the subject under discussion: There are numerous ways to deal with povertyalleviation, some of which are;

Firstly, Monetary Growth Approach (MGA) - Given the low work assimilation limit of the poverty implementation agencies, wide based financial development ought to be energized. This ought to concentrate on capital arrangement as it identifies with capital stock, and human capital. Human capital development needs to do with training, wellbeing, nourishment and lodging needs of work. This is clear from the way that interest in these features of human capital enhances the nature of work and in this way its profitability

Secondly, Essential Needs Approach(ENA)- This requires the procurement of fundamental needs, for example, sustenance, cover, water, sanitation, social insurance, fundamental training, transportation and so on. Unless there is appropriate focusing on, this methodology may not straightforwardly effect on the poor on 
account of their characteristic injury regarding political force and the capacity to impact the decision and area of government projects and activities.

Thirdly, Country Development Approach (CDA) - This methodology sees the provincial part as an exceptional area regarding povertylessening. This is on the grounds that dominant part of the poor in producing nations lives in this area. What's more, the level of paid job in this division is low which implies, conventional measures of mitigating poverty may not effectively work in the country segment without radical changes in the advantages possession structure, credit structure, and so on. Accentuation in this way to deal with advancement has concentrated on the Integrated Approach to country improvement. One essential issue with this way to deal with poverty decrease is that it is hard to center consideration on the genuine poor given that destitution in the country range is pervasive. At the end, it makes focusing of poverty decrease programs exceptionally troublesome and sometimes unrealizable.

Fourthly, Target Approach - This methodology favors coordinating poverty mitigation programs at particular gatherings inside the nation. Examples of such groupings are Social Safety Nets, Micro Credits, and farmer's groups program where necessary.

\section{POVERTY REDUCTION SCHEMES IN NIGERIA}

In Nigeria, the poverty easing measures executed so far have concentrated more on development, essential needs and country improvement approaches. They can be summarizedat a glimpse from two points of view as follows:

\section{VIII. $\quad$ FIRST AND SECOND PHASES OF POVERTY REDUCTION STRATEGIES IN NIGERIA}

Amid this period, poverty reduction was never the immediate center of improvement ordering and administration. Government just indicated sympathy toward poverty diminishment in a roundabout way. For instance, the purposes of the main National Development Plan in Nigeria incorporated the advancement of chances in wellbeing, work and training and in addition change of access to these open doors. These endpoints, if accomplished could doubtlessly prompt poverty mitigation. Consistently, the Fourth National Development Plan, which gave off an impression of being more exact in the particular of destinations that are related with poverty lessening, heightened increment in genuine pay of the normal resident also as decrease of wage disparity, in addition to other things (see Ogwumike, 1987 and 1998).

Amid this current time's national advancement arranges, a hefty portion of the projects which were sited in place in Nigeria by the administration (either entirely or in relationship with worldwide offices) affected poverty decrease in spite of the fact that the objective populace for a portion of the projects were not determined expressly as poor individuals or groups (Ogwumike, 1995 and 1998). Some of such projects are, the River Basin Development Authorities (RBDA), the Agricultural Development Programs (ADP), the Agricultural Credit Ensure Scheme (ACGS), the Rural Electrification Scheme (RES), and the Rural Saving money Program (RBP). The majority of these projects were intended to deal with such goals as livelihood era, upgrading agrarian yield and wage, also, stemming the tide of country - urban relocation, which most likely influenced poverty decrease. In spite of some critical level of achievement made by some of these projects, the majority of them couldn't be managed. Indeed, with time, a considerable lot of them fizzled as an aftereffect of preoccupation from the first core interest. Case in point, the Rural Banking and the Agricultural Credit Guarantee Scheme at numerous stages neglected to convey the craved credit for agrarian and rustic change in light of the fact that a ton of investment funds were assembled in the country regions just to be occupied to urban regions in type of credits/speculations. Other outstanding destitution decrease related projects that were set up in Nigeria before the approach of the Structural Adjustment Program (SAP) incorporate Operation Feed the Nation (OFN) set up in 1977, Free and Compulsory essential Education (FCPE) set up likewise in 1977, Green Revolution built up in 1980, and Low-Cost Housing Scheme. Both OFN and Green Revolution were set up to support agrarian generation and enhance the general execution of the farming division in addition to other things. These projects had some commendable effects; they upgraded the personal satisfaction of numerous Nigerians. Be that as it may, the projects couldn't be supported because of absence of political will and responsibility, arrangement precariousness and deficient inclusion of the recipients in these projects.

Cognizant strategy exertion by government towards poverty reduction started in Nigeria amid the period of the Structural Adjustment Program (SAP). The serious monetary emergency in Nigeria in the mid1980s declined the personal satisfaction of generally Nigerians. The administration tried to check the emergency through the appropriation of SAP. Notwithstanding, the execution of SAP further declined the living states of numerous Nigerians particularly poor people who were the most defenseless gathering. This made the administration to outline and execute numerous poverty easing programs somewhere around 1986 and 1993. Additionally, under the guided deregulation that spread over the period1993 to 1998, more poverty reduction programmes were put in place by government. Oladeji and Abiola (1998) identified them as: The Directorate for Foods Roads and Rural Infrastructures (DFFRI), the National Directorate for Employment (NDE), Better Life 
Programme (BLP), People's Bank of Nigeria (PBN), Community Banks (CB), Family Support Programme (FSP) and the Family Economic Advancement Programme (FEAP).

\section{ANALYZING POVERTY ALLEVIATION PROGRAMS (1999 - 2016)}

In 1999 when the Obasanjo regime came to power, it was evaluated that more than $70 \%$ of Nigerians lived in penury. That was the reason, in November 1999, the N470 billion Budget for year 2000 was to calmpoverty. Prior to the National Assembly even passed the 2000 Budget the administration got an endorsement to submit N10 billion to poverty mitigation program (Ogwumike, 2001). Poverty mitigation was seen as methods through which the administration could reproduce the economy and modify self-regard in lion's share of Nigerians. Among the povertyreducing projects were; the starting of Universal Basic Education (UBE) Program, the Poverty Alleviation Program (PAP) and the National Poverty Eradication Program (NAPEP)

\section{POVERTY ALLEVIATION PROGRAM (PAP)}

This project was acquainted in 2000 with location, the issues of rising unemployment and wrongdoing rates particularly among the young. The essential targets of this policy was to reduce the issue of unemployment and subsequently bring compelling interest up in the economy, increase the productiveness of the economy and drastically diminish the humiliating wrongdoing wave in the general public. However, the objectives/segments of PAP as distinguished by Obadan (2001) incorporate the followings; provide occupations for 200,000 unemployed, create a credit conveyance framework from which ranchers will have entry to credit offices, increase the grown-up proficiency rate from $51 \%$ to $70 \%$ by 2003 and to shoot up medicinal services conveyance framework from its present $40 \%$ to $70 \%$ by year 2003 .Others are to raise rustic water supply from $30 \%$ to $60 \%$ and same for provincial charge, embark on preparing and achievement of no less than $60 \%$ of tertiary establishments' graduates and A few measures were advanced keeping in mind the end goal to accomplish the above destinations and they incorporate among others; increment in the compensation of publicworkers, defense of associations and strategies inside the framework, especially that of the current poverty mitigation administrations, empowering and remunerating every single meriting Nigerian for industry and venture, significant reduction of streets for simple and illegitimate procurement of riches and the starting of the Universal Basic Education Program.

\section{REVIEWING POVERTY ALLEVIATION PROGRAM (PAP)}

Taking a glimpse at the purposes of PAP, one can conclude that it was intended to touch all part of povertyranging from supreme to territorial neediness. It was however more particular in controlling unemployment subsequently raising the pay of people so that their spending would increment and henceforth their necessities be fulfilled. However like in many projects, PAP was ruined by poor execution and being transient in nature it needed congruity. The point of the project was vanquished as credits given to fund smaller scale undertakings were not used by the recipients in such endeavors implying that the objective for job era was missed. PAP was additionally seen as activity of the decision gathering's system and in this manner was not given much consideration and, now and again, opposed by CEOs of states controlled by the resistance parties. For instance, Obadan (2001) watched that in the year 2000, "there were reports that the Alliance for Democracy (AD) governors of south west zone of the nation were troubled that the People Democratic Party (PDP) at the inside might have imagined the PAP for key political increases. Without a doubt there were affirmations of AD governors conflicting with the PAP keeping in mind the end goal to baffle the PDP government. In spite of the issues experienced over the span of execution of PAP, Oyiza (2003) noticed that it has succeeded in giving 82,000 employments to various types of individuals the nation over.

\section{NATIONAL POVERTY ERADICATION PROGRAM (NAPEP)}

The project was presented in 2001. It was gone for the procurement of "systems for the annihilation of outright destitution in Nigeria" (FRN, 2001) It was supplemented by the National Poverty Eradication Council (NAPEC) which was to organize the poverty reduction related exercises of all the applicable Ministries, Parastatals and Agencies. The chamber had the command to guarantee that the extensive variety of exercises were midway arranged, composed and supplement each other so that the destinations of approach progression and supportability were accomplished. The poverty decrease related exercises of the applicable establishments under NAPEP have been arranged into four categories:

1. Youth Empowerment Scheme (YES) which manages limit securing, compulsory connection, efficiency change, credit conveyance, innovation and advancement and undertaking advancement.

2. Rural Infrastructure Development Scheme (RIDS) this arrangements with the procurement of consumable and irrigating system, water transport (rustic and urban), provincial vitality and force support

3. Social Welfare Service Scheme (SOWESS) this arrangements with a custom curriculum, essential human services administrations, foundation and upkeep of recreational focuses, open mindfulness offices, youth and 
understudies inns improvement, natural insurance offices, sustenance security procurements, small scale and large scale credits conveyance, rustic information transfers offices, procurement of mass travel, and support society. - Natural Resource Development and Conservation Scheme (NRDCS) these arrangements with tackling of agrarian, water, strong mineral assets, preservation of area and space especially for advantageous and powerful usage by little scale administrators and the quick group.

\section{NATIONAL POVERTY ERADICATION PROGRAM} (NAPEP) - AN APPRAISAL

NAPEP was focused on youth strengthening, procurement of bases, social welfare plan and common asset advancement/protection. It was however expansive based and enveloping. It attempted to receive the participatory, base up methodology in system execution and checking. Nonetheless, a basic evaluation of NAPEP uncovered that it focused more on the Youth EmpowermentScheme (YES) disregarding alternate commands; even the YES itself concentrated more on the payment and organization of NAPEP's vehicle prevalently called "KEKE NAPEP" On the issue of characteristic asset improvement and preservation plan, Abdu (2005) watched that under $20 \%$ of the objective recipients have profited through this plan. This implies NAPEP has not had much effect in tackling horticultural, water and strong minerals assets and protection endeavors particularly in the rustic territories where the primary occupation is farming.

It has likewise been watched that a large portion of the destitute individuals have not took an interest in NAPEP's projects because of absence of access to social and financial bases contributed to enhance human capital. All things considered the nearby individuals were excluded in the ID of undertakings implying that the ones distinguished were as a rule, wrong and unsustainable. It was additionally seen by Abdu (2005) that in many regions, the credit offices and different bases gave by NAPEP were appreciated by individuals from the decision party while those recognized as restriction were denied get to and did not profit by the project in this way staying in neediness. To crown everything, even where the decision party supporter were given the credit offices, the assets were as a rule used for different purposes the consequence of which was that, over the long haul the planned recipients stayed poor.

One of the best accomplishments of both PAP and NAPEP was the achievement of the projects in giving occupations to various youth the nation over. Through NAPEP's Youth Empowerment Scheme, a ton of unemployed youth obtained entrepreneurial and business aptitudes in numerous regions bringing about the relative increment in their pay levels. The Universal Basic Education which is a methodology utilized by PAP in expanding proficiency rate likewise had an effect in numerous groups where classrooms were developed and learning materials accommodated the advantage of the natives.

However a ton of issues have been experienced during the time spent actualizing the projects. These issues incorporates: absence of contribution (by and large) of the neighborhood individuals in the distinguishing proof of tasks, authoritative and operational issues or more all, the disappointment in the choice of the objective recipients because of political reasons.

One of the recent poverty reduction strategies adopted by government in Nigeria is the Subsidy Reinvestment and Empowerment Programme (Sure-P). The introduction of the Subsidy Reinvestment and Empowerment Programme (SURE-P) was to reinvest the Federal Government's share of the savings arising from the reduction of subsidies on petroleum products into programmes and initiatives that would go a long way to ease the pain of subsidy removal and create a better life for Nigerians. Sure -P programme therefore ensures that the Federal Government's part of the savings from fuel subsidy removal or reduction is applied on critical infrastructure projects and social safety net programmes that will directly ameliorate the sufferings of Nigerians and mitigate the impact of subsidy removal.

The Sure-P program area of coverage will include but not limited to; National Primary Health Care Development Agency (Maternal and Child Health (Mch) Programme), Community Services, Women and Youth Empowerment (CSWYE), Graduate Internship Scheme (GIS), SURE-P Public Works, and SURE-P Vocational Training. Others include SURE-P Funds and training; SURE-P Roads \& Bridges and SURE-P Rail Way. The objectives of the programme that has direct bearing to poverty reduction includes among others to mitigate the immediate impact of the petroleum subsidy discontinuation on the population, but particularly for the poor and vulnerable segments. This applies to both the direct and indirect effects of subsidy withdrawal.To accelerate economic transformation through investments in critical infrastructure projects, so as to drive economic growth and achieve the Vision 20: 2020. And lastly to lay a foundation for the successful development of a national safety net programme that is better targeted at the poor and most vulnerable on the continuous basis.

Finally, one of the major reasons for these policies by governments was to ameliorate or totally eliminate poverty in Nigeria. Globally and Nigeria in particular, poverty has always remained an enormous challenge for the Nigerian Government suffice to say that the current trends indicate a significant growth in unemployment and illiteracy which are linked with the high level of poverty in our society (Okorie, 2003). The question now is 
whether the policies and the governments have succeeded in addressing this great social problem or not. Only the analysis will justify that.

\section{METHODOLOGY}

The research adopts the survey instrument for data collection. Data were collected by administering questionnaireto determine the performance of poverty reduction strategies/policies adopted by governments in Bauchi state. 250 questionnaires were randomly distributed to the residents of Bauchi metropolis as presented below

RESULTS - DATA ANALYSIS AND PRESENTATIONS

\begin{tabular}{|c|c|c|c|c|c|c|}
\hline $\mathrm{S} / \mathrm{N}$ & STATETMENT & SA & A & $\mathrm{U}$ & $\mathrm{D}$ & SD \\
\hline & Impact of Poverty Reduction Policies & & & & & \\
\hline 1 & $\begin{array}{l}\text { The implementation of government } \\
\text { policies on poverty reduction has not } \\
\text { impacted positively on the lives of the } \\
\text { people of Bauchi state }\end{array}$ & $\begin{array}{l}190 \\
(77.5 \%)\end{array}$ & $\begin{array}{l}20 \\
(8.2 \%)\end{array}$ & $\begin{array}{l}5 \\
(2.0 \%)\end{array}$ & $\begin{array}{l}20 \\
(8.2 \%)\end{array}$ & $\begin{array}{l}10 \\
(4.1 \%)\end{array}$ \\
\hline 2 & $\begin{array}{l}\text { The Impact of Poverty alleviation } \\
\text { programmes/policies in Bauchi state has } \\
\text { covered the entire state. }\end{array}$ & $\begin{array}{l}14 \\
(5.7 \%)\end{array}$ & $\begin{array}{ll}16 \\
(6.5 \%)\end{array}$ & $\begin{array}{l}165 \\
(67.3 \%)\end{array}$ & $\begin{array}{l}40 \\
(16.4 \%)\end{array}$ & $\begin{array}{l}10 \\
(4.1 \%)\end{array}$ \\
\hline 3 & $\begin{array}{l}\text { The implementation of Bauchi state } \\
\text { poverty reduction policies is biased } \\
\text { based on its areas of coverage }\end{array}$ & $\begin{array}{l}138 \\
(56.3 \%)\end{array}$ & $\begin{array}{l}22 \\
(9.0 \%)\end{array}$ & $\begin{array}{l}46 \\
(18.8 \%)\end{array}$ & $\begin{array}{l}14 \\
(5.7 \%)\end{array}$ & $\begin{array}{l}25 \\
(10.2 \%)\end{array}$ \\
\hline 4 & $\begin{array}{l}\text { Poverty reduction policies of } \\
\text { governments have not lived up to } \\
\text { expectation in terms of desired change in } \\
\text { Bauchi State }\end{array}$ & $\begin{array}{l}203 \\
(82.9 \%)\end{array}$ & $\begin{array}{l}26 \\
(10.6)\end{array}$ & $\begin{array}{l}11 \\
(4.5 \%)\end{array}$ & $\begin{array}{l}4 \\
(1.6 \%)\end{array}$ & $\begin{array}{l}1 \\
(0.4 \%)\end{array}$ \\
\hline \multirow[t]{3}{*}{5} & $\begin{array}{l}\text { The programmes of governments on } \\
\text { poverty reduction have been } \\
\text { implemented in Bauchi State }\end{array}$ & $\begin{array}{l}9 \\
(3.7 \%)\end{array}$ & $\begin{array}{l}21 \\
(8.6 \%)\end{array}$ & $\begin{array}{l}31 \\
(12.7 \%)\end{array}$ & $\begin{array}{l}16 \\
(6.5 \%)\end{array}$ & $\begin{array}{l}168 \\
(68.6 \%)\end{array}$ \\
\hline & Total & $\begin{array}{l}\mathbf{5 5 4} \\
(45 \%)\end{array}$ & $\begin{array}{l}105 \\
(8.6 \%)\end{array}$ & $\begin{array}{l}258 \\
(21.1)\end{array}$ & $\begin{array}{l}94 \\
(7.7 \%)\end{array}$ & $\begin{array}{l}214 \\
(17.5 \%)\end{array}$ \\
\hline & $\begin{array}{l}\text { Assessment of Government Policies on } \\
\text { Poverty reduction }\end{array}$ & & & & & \\
\hline 1 & $\begin{array}{l}\text { I am fully aware of the existence of } \\
\text { government policies towards poverty } \\
\text { reduction }\end{array}$ & $\begin{array}{l}149 \\
(60.9 \%)\end{array}$ & $\begin{array}{l}16 \\
(6.5 \%)\end{array}$ & $\begin{array}{l}21 \\
(8.6 \%)\end{array}$ & $\begin{array}{l}14 \\
(5.7 \%)\end{array}$ & $\begin{array}{l}45 \\
(18.4 \%)\end{array}$ \\
\hline 2 & $\begin{array}{l}\text { I have the perception that the } \\
\text { beneficiaries of these policies have fully } \\
\text { understood its objectives }\end{array}$ & $\begin{array}{l}38 \\
(15.5 \%)\end{array}$ & $\begin{array}{l}5 \\
(2.0 \%)\end{array}$ & $\begin{array}{l}15 \\
(6.1 \%)\end{array}$ & $\begin{array}{l}10 \\
(4.1 \%)\end{array}$ & $\begin{array}{l}177 \\
(72.2 \%)\end{array}$ \\
\hline 3 & $\begin{array}{l}\text { Poverty related policies and programs is } \\
\text { well understood and appreciated in } \\
\text { Bauchi State }\end{array}$ & $\begin{array}{l}27 \\
(11.0 \%)\end{array}$ & $\begin{array}{l}6 \\
(2.4 \%)\end{array}$ & $\begin{array}{l}63 \\
(25.7 \%)\end{array}$ & $\begin{array}{l}5 \\
(2.0 \%)\end{array}$ & $\begin{array}{l}144 \\
58.8 \%)\end{array}$ \\
\hline 4 & $\begin{array}{l}\text { Poverty reduction strategies have } \\
\text { performed well in raising the social } \\
\text { status of beneficiaries in Bauchi State }\end{array}$ & $\begin{array}{l}143 \\
(58.4 \%)\end{array}$ & $\begin{array}{l}17 \\
(6.9 \%)\end{array}$ & $\begin{array}{l}42 \\
(17.1 \%)\end{array}$ & $\begin{array}{l}18 \\
(7.3 \%)\end{array}$ & $\begin{array}{l}25 \\
(10.2 \%)\end{array}$ \\
\hline \multirow[t]{3}{*}{5} & $\begin{array}{l}\text { The establishment of entrepreneurial } \\
\text { centres has not reduced poverty level in } \\
\text { Bauchi State }\end{array}$ & $\begin{array}{l}137 \\
(55.9 \%)\end{array}$ & $\begin{array}{l}48 \\
(19.6 \%)\end{array}$ & $\begin{array}{l}23 \\
(9.4 \%)\end{array}$ & $\begin{array}{l}11 \\
(4.5 \%)\end{array}$ & $\begin{array}{l}26 \\
(10.6 \%)\end{array}$ \\
\hline & Total & $\begin{array}{l}494 \\
(40.3 \%)\end{array}$ & $\begin{array}{l}92 \\
(7.5 \%)\end{array}$ & $\begin{array}{l}164 \\
(13.4 \%)\end{array}$ & $\begin{array}{l}58 \\
(4.7 \%)\end{array}$ & $\begin{array}{l}417 \\
(34.0)\end{array}$ \\
\hline & $\begin{array}{l}\text { Efficiency of } \text { Entrepreneurial } \\
\text { Development Centres in Bauchi state }\end{array}$ & & & & & \\
\hline 1 & $\begin{array}{l}\text { A number of entrepreneurial } \\
\text { development centres were created in } \\
\text { Bauchi state and are working very } \\
\text { effective }\end{array}$ & $\begin{array}{l}4 \\
(1.6 \%)\end{array}$ & $\begin{array}{l}7 \\
(2.9 \%)\end{array}$ & $\begin{array}{l}15 \\
(6.1 \%)\end{array}$ & $\begin{array}{l}20 \\
(8.2 \%)\end{array}$ & $\begin{array}{l}199 \\
(81.2 \%)\end{array}$ \\
\hline 2 & $\begin{array}{l}\text { Employment opportunities were created } \\
\text { by these policies in Bauchi state through } \\
\text { entrepreneurial development centres }\end{array}$ & $\begin{array}{l}162 \\
(66.1 \%)\end{array}$ & $\begin{array}{l}25 \\
(10.2 \%)\end{array}$ & $\begin{array}{l}28 \\
(11.4 \%)\end{array}$ & $\begin{array}{l}16 \\
(6.5 \%)\end{array}$ & $\begin{array}{l}14 \\
(5.7 \%)\end{array}$ \\
\hline
\end{tabular}


Tetfund Sponsored Institutional Based Research (IBR) 2016

\begin{tabular}{|c|c|c|c|c|c|c|}
\hline 3 & $\begin{array}{l}\text { The establishment of entrepreneurial } \\
\text { centres has not reduced poverty level in } \\
\text { Bauchi State }\end{array}$ & $\begin{array}{l}7 \\
(2.9 \%)\end{array}$ & $\begin{array}{l}5 \\
(2.0 \%)\end{array}$ & $\begin{array}{l}24 \\
(9.8 \%)\end{array}$ & $\begin{array}{l}4 \\
(1.6 \%)\end{array}$ & $\begin{array}{l}205 \\
(83.7 \%)\end{array}$ \\
\hline 4 & $\begin{array}{l}\text { The entrepreneurial centres in Bauchi } \\
\text { state are managed well by agencies } \\
\text { responsible for the successes of poverty } \\
\text { reduction }\end{array}$ & $\begin{array}{l}81 \\
(33.1 \%)\end{array}$ & $\begin{array}{l}49 \\
(20.0 \%)\end{array}$ & $\begin{array}{l}17 \\
(6.9 \%)\end{array}$ & $\begin{array}{l}18 \\
(7.3 \%)\end{array}$ & $\begin{array}{l}80 \\
(32.7 \%)\end{array}$ \\
\hline \multirow[t]{3}{*}{5} & $\begin{array}{l}\text { Problem encountered by stake holders in } \\
\text { entrepreneurial centres are addressed } \\
\text { immediately for efficiency and } \\
\text { effectiveness of policies on poverty } \\
\text { reduction }\end{array}$ & $\begin{array}{l}23 \\
(9.4 \%)\end{array}$ & $\begin{array}{l}17 \\
(6.9 \%)\end{array}$ & $\begin{array}{l}169 \\
(68.9 \%)\end{array}$ & $\begin{array}{l}11 \\
(4.5 \%)\end{array}$ & $\begin{array}{l}25 \\
10.2 \%)\end{array}$ \\
\hline & Total & $\begin{array}{l}277 \\
(22.6 \%)\end{array}$ & $\begin{array}{l}103 \\
(8.4 \%)\end{array}$ & $\begin{array}{l}253 \\
(20.7)\end{array}$ & $\begin{array}{l}699 \\
(5.6 \%)\end{array}$ & $\begin{array}{l}523 \\
(42.7 \%)\end{array}$ \\
\hline & $\begin{array}{l}\text { State of Unemployment in Bauchi } \\
\text { Local Government }\end{array}$ & & & & & \\
\hline 1 & $\begin{array}{l}\text { I have the belief that unemployment has } \\
\text { greatly been reduced by poverty } \\
\text { alleviation programmes introduced by } \\
\text { Bauchi state governments }\end{array}$ & $\begin{array}{l}41 \\
(16.7 \%)\end{array}$ & $\begin{array}{l}35 \\
(14.3 \%)\end{array}$ & $\begin{array}{l}114 \\
(46.5 \%)\end{array}$ & $\begin{array}{l}20 \\
(8.2 \%)\end{array}$ & $\begin{array}{l}35 \\
(14.3 \%)\end{array}$ \\
\hline 2 & $\begin{array}{l}\text { Unemployed lack basic knowledge on } \\
\text { poverty alleviation programmes of } \\
\text { Government }\end{array}$ & $\begin{array}{l}123 \\
(50.2 \%)\end{array}$ & $\begin{array}{l}17 \\
(6.9 \%)\end{array}$ & $\begin{array}{l}60 \\
(24.5 \%)\end{array}$ & $\begin{array}{l}26 \\
(10.6 \%)\end{array}$ & $\begin{array}{l}19 \\
(7.8 \%)\end{array}$ \\
\hline 3 & $\begin{array}{l}\text { Unemployed are reluctant to participate } \\
\text { in poverty alleviation programmes of } \\
\text { Government }\end{array}$ & $\begin{array}{l}15 \\
(6.1 \%)\end{array}$ & $\begin{array}{l}19 \\
(7.8 \%)\end{array}$ & $\begin{array}{l}29 \\
(11.8 \%)\end{array}$ & $\begin{array}{l}21 \\
(8.6 \%)\end{array}$ & $\begin{array}{l}161 \\
(65.7 \%)\end{array}$ \\
\hline 4 & $\begin{array}{l}\text { Poverty reduction programmes of } \\
\text { Government has not met the expectation } \\
\text { of the people in terms of employment } \\
\text { generation }\end{array}$ & $\begin{array}{l}99 \\
(40.4 \%)\end{array}$ & $\begin{array}{l}33 \\
(13.5 \%)\end{array}$ & $\begin{array}{l}48 \\
(19.6 \%)\end{array}$ & $\begin{array}{l}21 \\
(8.6 \%)\end{array}$ & $\begin{array}{l}44 \\
(17.9 \%)\end{array}$ \\
\hline \multirow[t]{2}{*}{5} & $\begin{array}{l}\text { The rural unemployed are not carried } \\
\text { along in Government poverty alleviation } \\
\text { policies }\end{array}$ & $\begin{array}{l}74 \\
(30.2 \%)\end{array}$ & $\begin{array}{l}14 \\
(5.7 \%)\end{array}$ & $\begin{array}{l}12 \\
(12.7 \%)\end{array}$ & $\begin{array}{l}10 \\
(4.1 \%)\end{array}$ & $\begin{array}{l}116 \\
(47.3 \%)\end{array}$ \\
\hline & Total & $\begin{array}{l}195 \\
(15.9) \\
\end{array}$ & $\begin{array}{l}118 \\
(9.6 \%) \\
\end{array}$ & $\begin{array}{l}439 \\
(35.8 \%) \\
\end{array}$ & $\begin{array}{l}98 \\
(8.0 \%) \\
\end{array}$ & $\begin{array}{l}375 \\
(30.6) \\
\end{array}$ \\
\hline
\end{tabular}

\section{DATA ANALYSIS AND PRESENTATION}

From the table above, the questionnaire is divided into four segments which answer the four objectives of the research. 554responses received, representing $45 \%$ of the total sample strongly agreed that the implementation of government policies on poverty reduction has not impacted positively on the lives of the people of Bauchi state, even though the coverage of the Policies is the entire Local Governments area of Bauchi state and the implementation of poverty reduction policies is biased based on its areas of coverage. Poverty reduction policies of governments have not lived up to expectation in terms of desired change in Bauchi State and also the programmes of governments on poverty reduction have been implemented in Bauchi State. While 105 respondents representing $8.6 \%$ agreed to the statements, 258 respondents $(21.1 \%)$ were not sure. $7.7 \%$ (94 persons) disagreed and $214(17.5 \%)$ strongly disagreed

Secondly, on assessment of government policies on poverty alleviation in Bauchi state, responses received has 494 respondents representing 40.3\% affirming that some residents of Bauchi State are not aware of the existence of government policies towards poverty reduction but the beneficiaries of these policies have fully understood its objectives. Also, poverty related policies and programs is well understood and appreciated in Bauchi State. Other statements are poverty reduction strategies have performed well in raising the social status of beneficiaries in Bauchi State even though the establishment of entrepreneurial centres has not reduced poverty level in Bauchi State. 92 respondents representing 7.5\% agreed, 164 (13.5\%) undecided, $58(4.7 \%)$ disagreed while 417 (34.0\%) strongly disagreed to the statements.Thirdly, onthe efficiency of entrepreneurial centres in Bauchi state, respondents received agreed with 277 responses (22.6\%) that a number of entrepreneurial development centres were created in Bauchi state and are working very effective. Employment opportunities were created by these policies in Bauchi state through entrepreneurial development centres and the establishment of entrepreneurial centres has not reduced poverty level in Bauchi State. Other statements are the entrepreneurial centres in Bauchi state are managed well by agencies responsible for the 
successes of poverty reduction and Problem encountered by stake holders in entrepreneurial centres are addresse $\mathrm{d}$ immediately for efficiency and effectiveness of policies on poverty reduction. While 103 respondents $(8.4 \%)$ agreed, 253 respondents $(20.7 \%)$ undecided. A total of 69 responses (5.6\%) disagreed and $523(42.7 \%)$ responses received strongly disagreed to the statements on the efficiency of entrepreneurial centres.

Lastly, the state of unemployment in Bauchi local government was also determined. The responses received on statements; unemployment has greatly been reduced by poverty alleviation programmes in Bauchi state and unemployed lack basic knowledge on poverty alleviation programmes of Government. Hence, unemployed are reluctant to participate in poverty alleviation programmes of Government while Poverty reduction programmes of Government has not met the expectation of the people in terms of employment generation. The concluding statement on this is that the rural unemployed are not carried along in Government poverty alleviation policies. 195 respondents representing $15.9 \%$ strongly agreed to the above statements, $118(9.6 \%)$ agreed. While, 439 $(35.8 \%)$ undecided, $8.0 \%$ (98 respondents) disagreed and 375 (30.6\%) strongly disagreed.

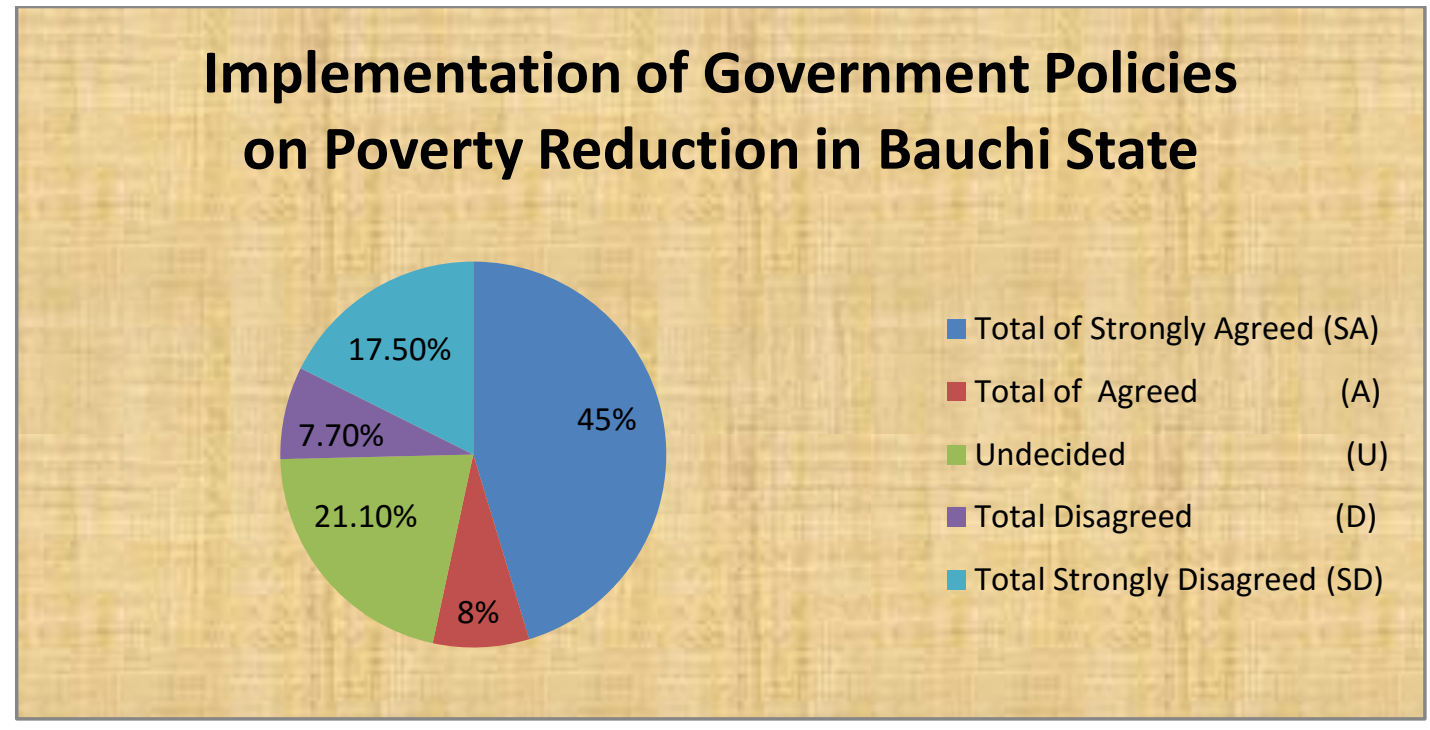

XVI.

\section{DISCUSSION ON FINDINGS}

From the data so far examined and presented, it is glaring that the concept under discussion has been exhaustively analyzed. On the first objective of this study, the larger percentage of 554 respondents representing $45 \%$ proved that poverty alleviation programmes have been implemented in the study area. Although a total of 258 responses $(21.1 \%)$ were not sure if these policies have been implemented, and 214 responses $(17.5 \%)$ strongly disagreed to the implementation of these policies towards poverty reduction in the state. A total of 105 respondents representing $8.6 \%$ also agreed that there were policies implementation in Bauchi state while, 94 respondents $(7.7 \%)$ disagreed to the implementation of the policies. 


\section{Implementation of Government Policies on Poverty Reduction in Bauchi State}

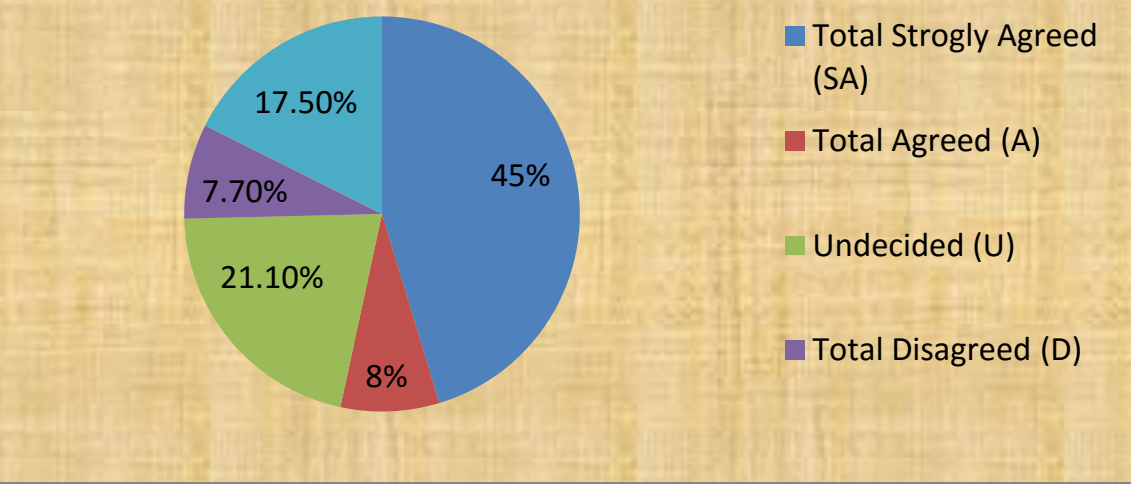

However, in assessing the government policies on poverty reduction, 494 representing $40.3 \%$ have accepted that poverty reduction policies have impacted positively on the lives of the people and that the policies and its objectives are understood. A substantive number of respondents totaling $417(34.0 \%)$ were not in conformity with the above assertions, while, $7.5 \%$ (92 respondents) also agreed that the policies have impacted on the lives of the people. 164 responses representing $(13.4 \%)$ have neither agreed nor disagreed to the positive impact of the policies and 58 respondents $(4.7 \%)$ also disagreed that the policies have touched lives.

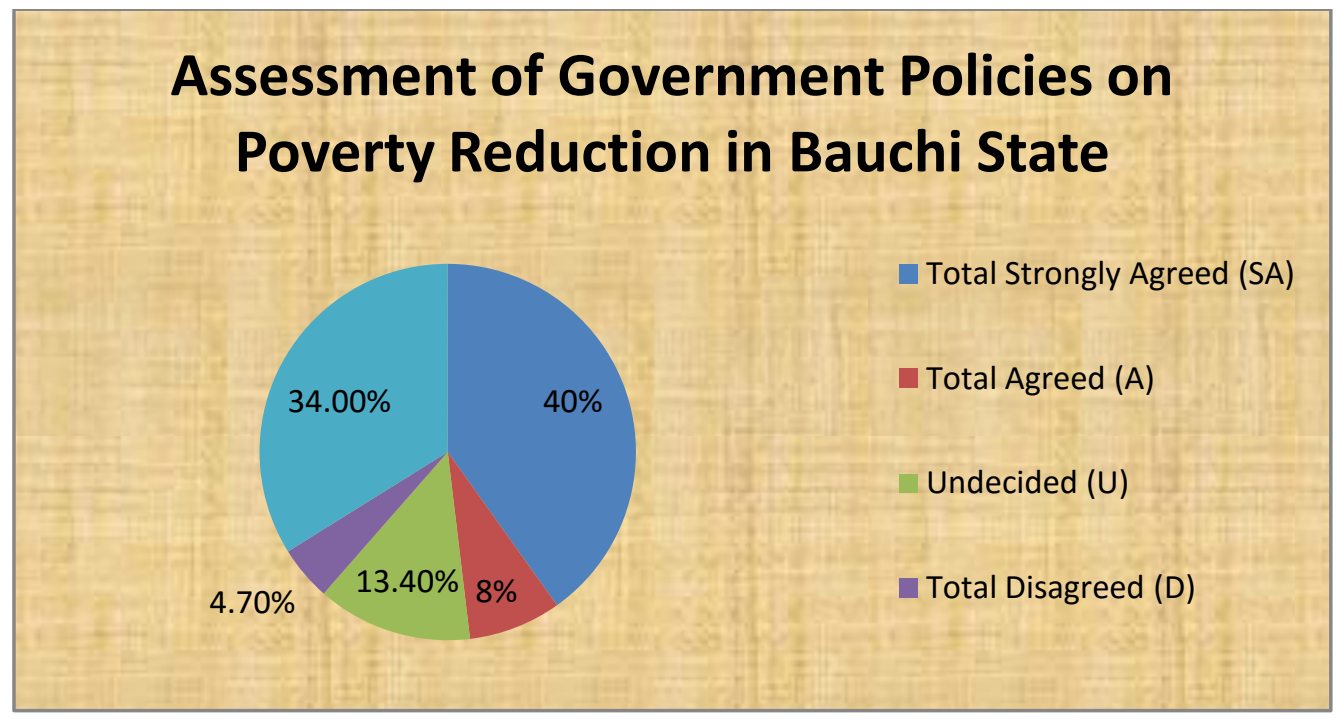

Furthermore, the efficiency and effectiveness of entrepreneurial centres in the study area received a deadly blow as 523 respondents representing $(42.7 \%)$ were of the view that few entrepreneurial centres in Bauchi state are not effective and therefore has not reduced the poverty level in the state because of poor management, corruption and misplacement of priorities hence all the problems encounters in these centres are not managed well for the successes of the poverty reduction policies. A total of 277 respondents (22.6\%) and 103 responses (8.4\%) strongly agreed and disagreed respectively to the earlier position. While 69 respondents $(5.6 \%)$ also agreed that the centres have not done well in the state and 253 responses $(20.7 \%)$ were neutral. 


\title{
The Efficiency and Effectiveness of Entreprenurial Development Centres
}

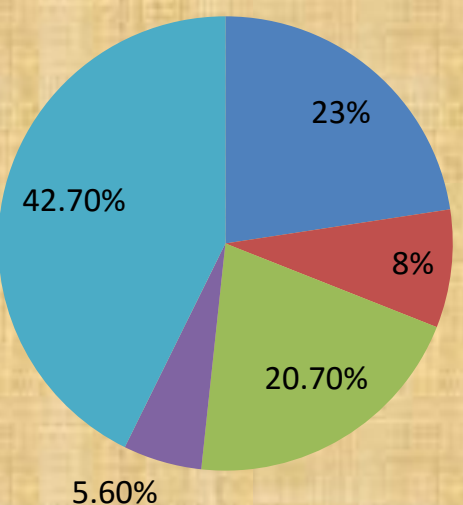

\author{
Total Strongly Agreed (SA) \\ Total Agreed (A) \\ Undecided (U) \\ Total Disagreed (D) \\ Total Strongly Disagreed \\ (SD)
}

Finally, in determining the state of unemployment in the state, the research reveals that Unemployment hasn't been reduced by poverty alleviation programmes in Bauchi state because of either the Unemployed lack the basic knowledge on poverty alleviation programmes of Government or are reluctant to participate in poverty alleviation programmes of Government and therefore has not met the expectation of the people in terms of employment generation. A total of 375 and 98 respondents representing $(30.6 \%)$ and $(8.0 \%)$ respectively confirmed that unemployment hasn't been reduced by poverty alleviation policies of governments in the state. While, 195 and 118 responses $(15.9 \%)$ and $(9.6 \%)$ respectively had a different perspective on employment in the study location and 439 respondents $(35.8 \%)$ prefer to be neutral.

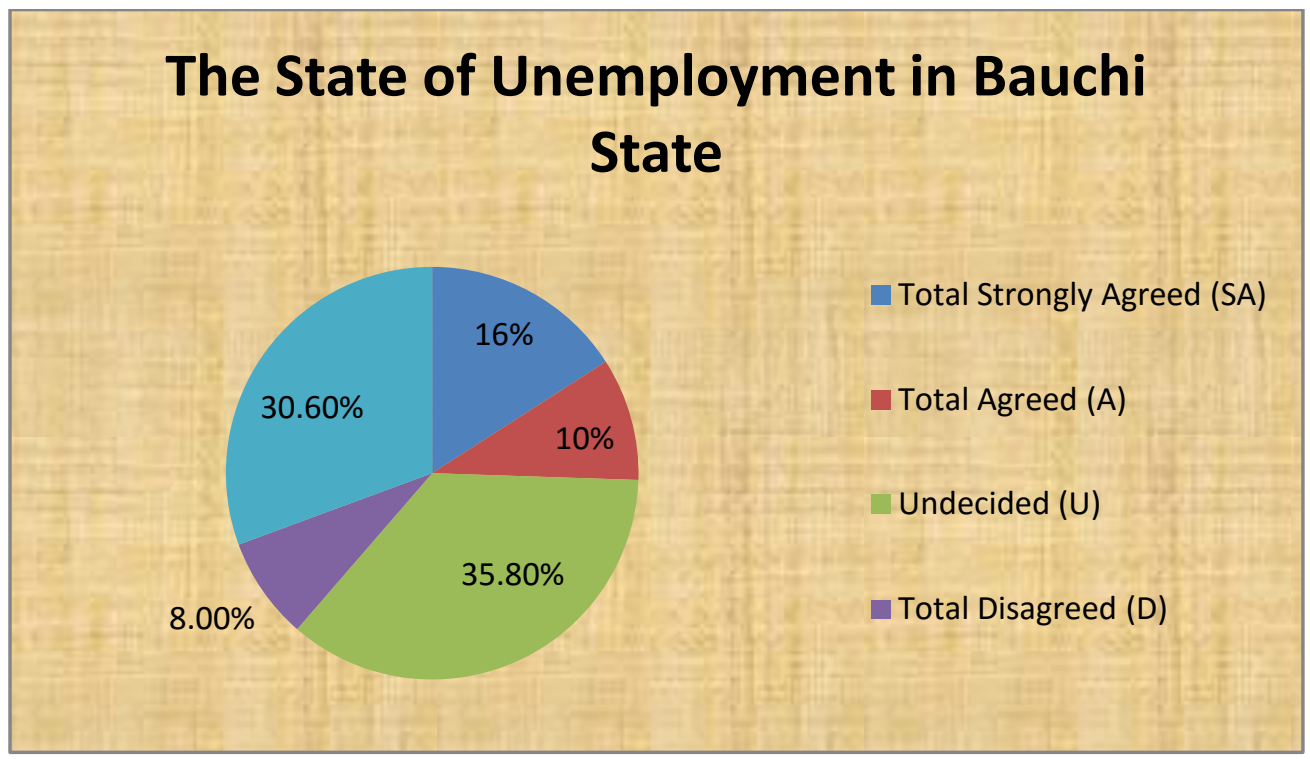

In conclusion, it can be deduced from the above therefore that poverty alleviation programmes have been implemented in the study area based on the research conducted and also confirmed that poverty reduction policies have impacted positively on the lives of the people and that the policies and its objectives are understood. However, the research reveals that the few entrepreneurial centres in Bauchi state are not effective and therefore has not reduced the poverty level in the state because of poor management, corruption and misplacement of priorities hence all the problems encounters in these centres are not managed well for the successes of the poverty reduction policies. Similar to that the research reveals that Unemployment hasn't been reduced by poverty alleviation programmes in Bauchi state because of either the Unemployed lack the basic knowledge on poverty alleviation programmes of Government or are reluctant to participate in poverty 
alleviation programmes of Government and therefore has not met the expectation of the people in terms of employment generation

\section{CONCLUSION AND RECOMMENDATIONS}

Considering the present poverty incidence in the nation, one can infer that the past poverty reducing programs have not accomplished much. This is maybe because of the issues distinguished as obstructing the powerful usage of the projects. The goals and order of both PAP and NAPEP were gone for procurement of vocation and pay era through different exercises; however absence of inclusion of the objective recipients in recognizing the right ventures combined with managerial and operational disappointments were among the issues distinguished as frustrating the accomplishment of the destinations of the projects.

There is consequently the requirement for organization of the immediate individuals in the distinguishing proof and outline of activities so that adequate support can be accomplished. Povertyalleviating projects ought to likewise be composed in such a path as to be feasible and ought to be equipped towards procurement of practical vocation so that over the long haul, their effects stream down to the grassroots. Also, to ease destitution successfully, there is the requirement for the administration to supply fundamental inputs that can enhance individuals' job, efficiency and expansion in their riches (wage). These inputs can be in type of manures, cultivating machines, seeds, preparing programs, expertise procurement programs, credit offices and others. The following itemized recommendations needs to be taken seriously:

The Government of Nigeria needs help, to meet the challenge of initiating an inclusive rapid growth with socialstructural transformation to strategize, prioritize, and to manage its own resources better. But such must be predicated on sound analysis and evaluation of the state of the economy.

2. Summarily, poverty reduction strategies in Nigeria, therefore, have to incorporate distributive features and high level of inclusiveness. This can be achieved by promoting human capital development.

3. Government should invest more in education sector, increase public spending on social services and enhance access to basic education and primary health care by building on existing government policy, provision of vocational training centers to equip youths, in particular for self-employment.

4, Public policy should go beyond building people's capacities into matching capacities with opportunities in order to significantly link the demand and supply of human capital. There is broad acceptance that rapid and sustained growth is the single most important way to reduce poverty. Growth accounts for more than 80 per cent of poverty reduction and has lifted about 600 million above the poverty line since 1980 (Ogujiubakanayo 2014). In the 1990s growth rates in thedeveloping world out-paced those in the developed world for the first time. Better growth performance in poor countries is therefore central to achieving the MDGs. Yet ensuring that more countries achieve and sustain high per capita growth rates remains a key fundamental.

5. There should be a quality infrastructure in the country that would facilitate business and provide the enabling climate importance for attracting domestic and foreign investments, adopting new technologies, and raising productivity.

6. To reduce poverty and improve the quality of life in Nigeria will require a sustained economic growth. However, the extent of poverty reduction would depend on the degree to which the poor participate in the growth process andshare in its proceeds. Improvements in human, physical and social capital of the poor are key fundamentals to increasing their ability to participate in growth. It is clear that both the pace and pattern of growth matter for poverty reduction (Abdulhadi A. (2003).

7. The challenge for policy streamlining is to combine growth promoting policies with the right policies for assuring that the poor fully participate in economic development. However, thechallenge for research is to improve knowledgeand understanding of what policies, technologiesandinvestments matter for sustained andinclusive growth in the country. (Kuznets (1971)

8. The selection of poverty reduction beneficiaries should be devoid ofpolitical sentiments but should be based on equity and fairness, so that every eligible youth willbenefit from the programme. Government should also provide the basic infrastructural facilitiessuch as good roads, stable power supply and logistic facilities for the smooth operation of theprogramme in the study area.

9. New poverty reduction strategies for Nigeria should be anchored on inclusive growth fundamentals, redistributive public expenditure, increasing rate of productive job creation and a broad based sectorial growth. (Abdu, H. (2005)

10. The research further recommends that growth should be broad-based, cutting across all sectors and inclusive of the large part of the workforce that poor men and women make up. New strategies should encompass the key elements of benefit incidence amongst the poor population, to supportNigeria's current development agenda (Transformation Agenda and Vision 20: 2020) of the previous administration and the change mantra of the current government significantly; against the factthat the 2015 achievement timeline wasn't successful 
11. The poverty reduction strategies should also include Agricultural expansion and mechanization. Ethical investments in agriculture are particularly important, because agriculture's potential is huge. With twothirds of Africans depending on farming, boosting agriculture is a highly effective way to reduce poverty and inequality.

12. The entrepreneurial development centres should be adequately equipped and given the requisite attention by government in order to serve as a hub of employment generation in the state. It will go a long way in minimizing the rate of unemployment in the study area.

13. Public enlightenment campaigns should also be intensified by government to guide the stake holders on the objectives of these policies and the need to understand and benefit from it.

\section{REFERENCES}

[1] Abdu, H. (2005), Impact of National Poverty Eradication Programme (NAPEP) onIncome Changes in Rural Areas Unpublished seminar paper, Abuja.

[2] Abiola, A. G. and Olaopa, O. R. (2008).Economic Development And Democratic Sustenance in Nigeria. In E. O. Ojo(ed), Challenges of Sustainable Democracy in Nigeria (pp. 25-34). Ibadan: John Archers Publishers Limited.

[3] Awa, E. O. (1983). Teaching Political Science in African Universities: A Problem Solving Approach. InY. Barongo (ed),Political Science in Africa (pp. 27-37). United Kingdom: Zed Press Plc.

[4] Ajaikaye, D.\&Adeyeye, V.(2001), Concepts, Measurements and Causes of PovertyCBN Executive Seminar, Ibadan.

[5] Aku P.S \&Oladeji, S.I(1997), Perspective on Poverty and Poverty Alleviation Strategies in Nigeria NES Annual Conference.

[6] Aliu, A.(2001), National Poverty Eradication Programme:Completion, Implenetation, Coordination and Monitoring NAPEP Abuja.

[7] Bradshaw, T.K. (2006), Theories of Poverty and Anti- Poverty Programs in Community Development http//:www.rprconline.org/

[8] Federal Republic of Nigeria. (2001). A Blueprint for the Schema of National Poverty Eradication Program (NAPEP), Abuja

[9] Galbraith, J.K. (1969), A Schema for Monitoring Poverty Alleviation Journal of Economics and Finance VOL 6 No2 Portland.

[10] Garba, A. (2006). Alleviating Poverty in Northern Nigeria. A paper presented at the annual convention of

[11] ZumuntaAssociation, Minneapolis, MN, USA. July 28-29.

[12] Myrdal, G. (1957), Economic Theory and Underdeveloped Regions. London Gerald Duckworth \& Co.

[13] Nwaobi, G.C. (2003). Solving the Poverty Crisis in Nigeria: An Applied General Equilibriumapproach.

[14] Quantitative Economic Research Bureau.Gwagwalada, Abuja.

[15] Obadan, M.I.(1997), Analytical Framework for Poverty Reduction: Issues of Economic Growth versus Other Strategies NES Annual Conference.

[16] Obadan, M.I. (2001), Poverty Reduction in Nigeria: The way Forward CBN Economic and Financial Review Vol. 39 No. 4

[17] Ogwumike, F.O. (1995), The Effect of Micro level Government Policies on Rural Development and Poverty Alleviation in Nigeria Ibadan JournalOf Social Sciences Vol. 1 No 1

[18] Ogwumike, F.O. (1998), Poverty Alleviation Strategies in NigeriaProceedigs of $7^{\text {th }}$ Annual Conference of the Zonal Research Unit of CBN

[19] Ogwumike, F.O. (2001), An appraisal of Poverty and Poverty Reduction Strategies

In Nigeria CBN Economic and Financial Review Vol. 39 No. 4

[20] Ojo, E. O. (2008). Imperatives of Sustaining Democratic Values. In Ojo, E. O (ed), Challengesof stainable Democracy in Nigeria (pp. 3-24). Ibadan: JohnArchers PublishersLimited.

[21] Okpe, I. J. and Abu, G. A. (2009).Foreign Private Investment and Poverty Reduction in Nigeria (19752003). J. Soc. Sci., 19(3), 205-211.

[22] Omotola, J.S. (2008). Combating Poverty for Sustainable Human Development in Nigeria:

The Continuing Struggle Journal of Poverty, 12(4), 496-517.

[23] Oladeji, S.I. \&Abiola, A.G. (1998), Poverty Alleviation with Growth Strategy : Pro-

[24] spects and Challenges in Contemporary Nigeria Nigerian Journal of Economic and Social Sciences NJESS Vol. 40 No. 1

[25] Oyiza, M.(2003), Poverty Alleviation Programs and Rural Development: Which Way ?Unpublished Seminar paper UNIBEN, Nigeria.

[26] Putman, R.D. (2000), Bowling Alone. New York: Simon Schuster.

[27] Rogers, E.M. (1998), Social Change in Rural Societies: An IntroductionTo Rural Sociology. Prentice Hall, New Jersey 
[28] UNDP (1997).Human Development Report 1997. New York: Oxford University Press.

[29] UNDP (2010) Human Development Report Nigeria 2008-2009. Achieving Growth with Equity. 